\title{
Diozonides from Coozonolyses of Cyclodienes and Carbonyl Compounds
}

\author{
Shin Hee Park and Tae Sung Huh * \\ Department of Chemistry, The Catholic Lniversity of Korea, Puchon +22-743, Korea \\ Received November 8,2001
}

\begin{abstract}
Treatment of conjugated cyclodienes (5a-5c) with excess ozone in dichoromethane in the presence of added carbonyl compounds (3) resulted to give the corresponding diozonides 10 and cross-ozonides 14. Similarly. ozonoly sis of the nonconjugated 1.4-cyclohexadiene (6a) and 1.5-cyclooctadiene (6b) under same conditions afforded both diozonides 20 and cross-ozonides 14. On the other hand. Ozonolysis of bicyclo[2.2.0]hepta-2.5diene (6c) in the presence of $3 \mathrm{~A}$ provided the corresponding diozonide 19.
\end{abstract}

Keywords : Diozonides. Coozonolỵses. Cyclodienes.

\section{Introduction}

Ozonolysis reactions of cyclodienes in nonparticipating solvents have not been studied extensively. ${ }^{1-4}$ Ozonation of cycloalkenes in anlydrous nonparticipating solvents result in the formation of polymeric ozonides because intramolecular cycloaddition of carbonyl oxides with aldehy'des are much slower than intermolecular reactions. In order to avoid the polymeric ozonides formation. a good 1.3-dipolarophile is needed to trap the carbonyl oxide intermediates. In previous work. we had shown that the carbonyl oxide intermediates $\mathbf{2}$. generated from the ozonolysis of cycloalkenes $\mathbf{1}$ can be trapped by carbonyl compounds 3 to form the corresponding ozonides 4.7

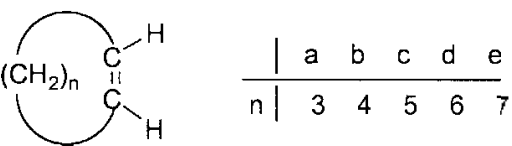

$$
\begin{aligned}
& 1 \\
& \mathrm{O}=\mathrm{CH}-\left(\mathrm{CH}_{2}\right)_{\mathrm{n}}-\stackrel{+}{\mathrm{C}} \mathrm{H}-\mathrm{O}-\mathrm{O}^{\circ} \\
& 2 \\
& O=C_{3}^{-R^{1}} \\
& \begin{array}{l|ll}
- & f & g \\
\hline R^{2} & H & \mathrm{CH}_{3} \\
R^{2} & \mathrm{CN}
\end{array} \\
& \mathrm{O}=\mathrm{CH}-\left(\mathrm{CH}_{2}\right)_{\mathrm{n}}-\mathrm{C}_{\mathrm{O}}^{\mathrm{O}-\mathrm{O}} X_{\mathrm{R}^{2}}^{\mathrm{R}^{1}}
\end{aligned}
$$

4

We have now extended this mode of reaction to the ozonolysis of conjugated cyclodienes $\mathbf{5 a - 5 c}$ and nonconjugated cyclodienes 6a-6c in presence of carbonyl compounds $3 \mathrm{f}$ and $\mathbf{3 g}$ to obtain the corresponding diozonides. respectively.<smiles>c1ccncc1</smiles>

5

$$
\begin{array}{l|lll} 
& a & b & c \\
\hline n & 2 & 3 & 4
\end{array}
$$<smiles>C1=CN2C=C[Al]C=C[Al]2C=C1</smiles>

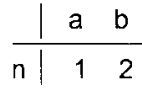

6

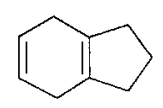

$6 \mathrm{c}$

\section{Results and Discussion}

In pursuit of our goal, we have ozonized the cojugated cyclodienes 5a-c in dichloromethane with excess of ozone in the presence of carbonyl compounds $\mathbf{3 f}$ and $\mathbf{3 g}$. respectively.

Ozonolyses of 1.3-cyclohexadiene (5a) and 1.3-cycloheptadiene (5b) and 1.3-cyclooctadiene $(\mathbf{5 c})$ in the presence of carbonyl compounds $3 \mathrm{f}$ and $\mathbf{3 g}$ afforded the corresponding diozonides 10c. 10d. 10e. 10f, 10g and 10h. which have been isolated in yields of $15.3 \%, 12.80 \%, 26.7 \% .24 .3 \%$. $28.2 \%$ and $31.2 \%$. respectively. By-products of these reactions were cross-ozonides $1+\mathbf{c}-\mathrm{h}$ in yields of $14.2-24.1 \%$. each. Ozonolyses of $\mathbf{5 a - c}$ with one equivalent of ozone under similar reaction conditions afforded the unsaturated ozonides 7 and 8 as major products. ${ }^{8}$ It can be concluded that ozone cleavage of the double bonds in unsaturated ozonides 7 and 8 occurs predominatly in one direction only. with the formation of higher subsituted carbonyl oxides $\mathbf{9}$ and $\mathbf{1 2}$. The fact that no ozonides 13 have been found in ozonolyses of $5 \mathrm{a}-\mathrm{c}$ could be due to the instability of $\alpha$-oxo ozonides of type 13. ${ }^{y, 1 i}$

Ozonolysis of the nonconjugated 1,4-cyclohexadiene (6a) in the presence of carbonyl compounds $\mathbf{3 f}$ provided the corresponding cross-ozonide 14a and diozonides 10a in yield of $8.0 \%$ and $79.3 \%$. Ozonoly sis of nonconjugated 1.5 cyclooctadiene (6b) in the presence of $\mathbf{3 f}$ and $\mathbf{3 g}$ provided the corresponding cross-ozonides $\mathbf{1 4 c}$ and $\mathbf{1 4 d}$ and diozonides 10c and 10d in yields of $25.3 \% .27 .3 \%, 30 \%$ and $28 \%$. respectively.

Ozonolysis of bicyclo[2.2.0]hepta-2,5-diene (6c) in the presence of $3 \mathrm{f}$ provided the corresponding diozonide $19 \mathrm{in}$ yield of $58.3 \%$. Ozonolysis of $6 \mathbf{c}$ with one equivalent of ozone under same condition afforded unsaturated ozonide 17 as a major product. ${ }^{11}$

All of the ozonides have been isolated by column cluromatography on silica gel. Diozonides 10d. 10f and $10 \mathrm{~h}$ were mixture of diastereoisomers at the ozonide rings. ${ }^{13.13}$

The structures of all isolated ozonides were established by ${ }^{1} \mathrm{H}$ and ${ }^{13} \mathrm{C}$ NMR spectroscopy, and their reduction with triphenylphosphine to give the expected dials and carbonyl compounds 3 in a ratio of $c a .1: 1$.

In the ${ }^{1} \mathrm{H}$ NMR spectra. the ozonide moieties of the crossozonides could be recognized by signals of the $\mathrm{CH}$ groups in the ozonide rings. They appeared in the range of $\delta=5.03$. 


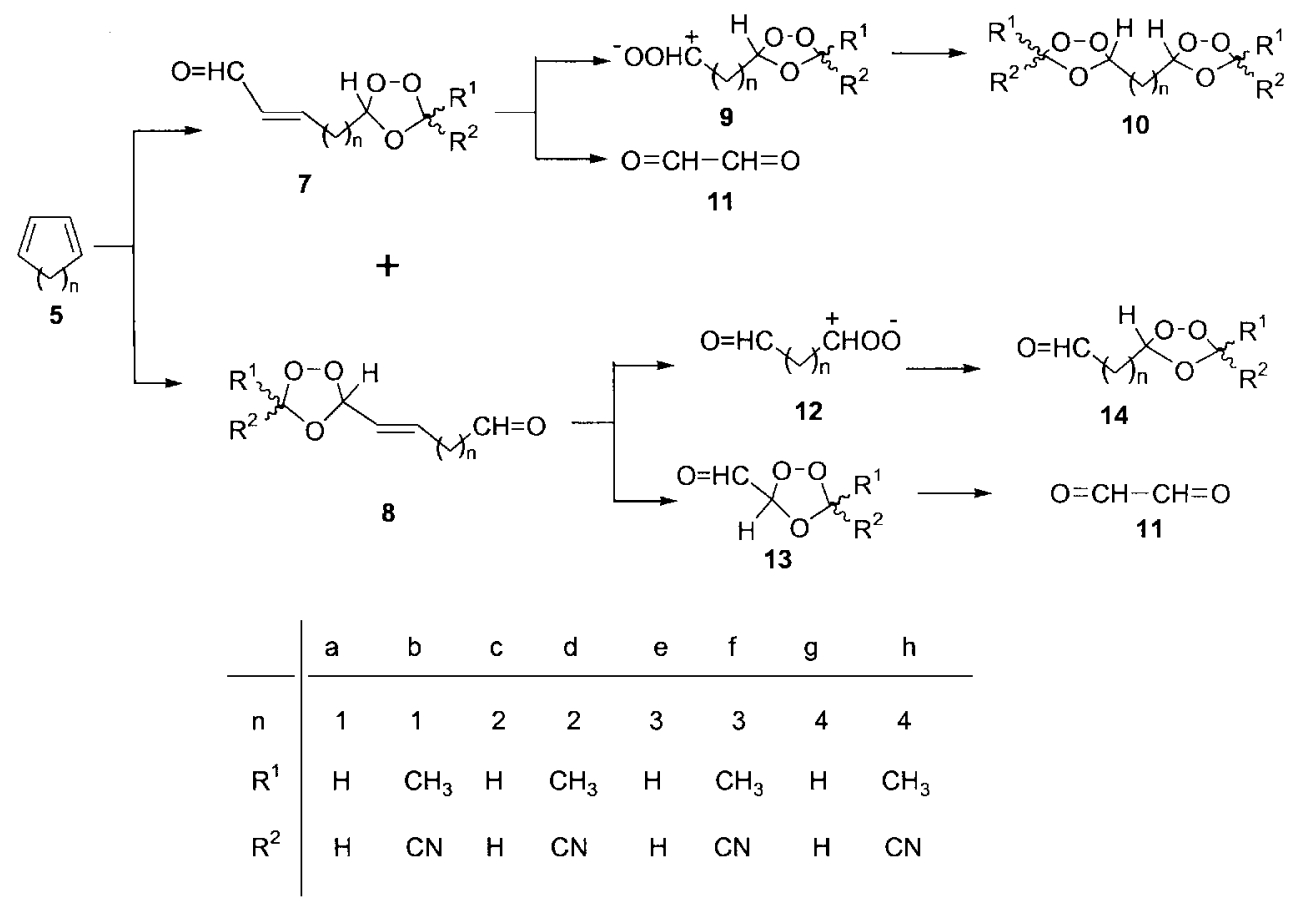

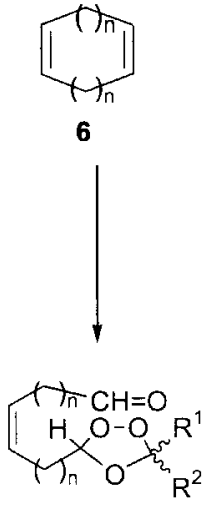

15

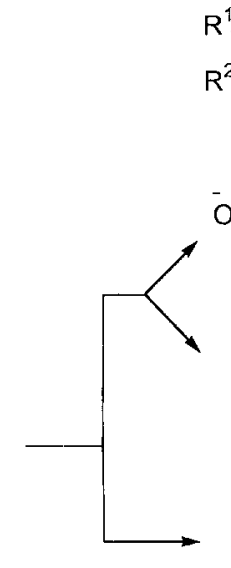<smiles>CC12CC=CCC(=O)C1OOC2</smiles>

17<smiles>O=CCC1(CC(=O)CC(=O)[O-])OCCO1</smiles>

18<smiles>[2H][C@H]1OOC(CC(=O)CC2(CC)OOO2)O1</smiles>

19<smiles>O=CC[Te]C([18F])O[O-]</smiles>

12<smiles>[3H][3H]</smiles>

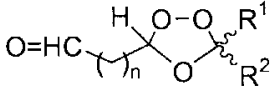

14

5.30. In the ${ }^{13} \mathrm{C}$ NMR spectra of all ozonides. the two chemically nonequvalent carbon atoms in the ozonide ring exhibited signals in the range of $\delta=93.82-114.04 .^{7}$

The successful coozonolysis of the cyclodienes in the presence of carbonyl compounds opens a convenient shortpath synthesis for the types of diozonides $\mathbf{1 0}$ and 17.

\section{Experimental Section}

NMR spectra: Brucker AC-300. ' $\mathrm{H}-\mathrm{NMR}$ and ${ }^{13} \mathrm{C}-\mathrm{NMR}$ spectra were recorded in $\mathrm{CDCl}_{3}$ with TMS as internal references. Chronatographic separations: Flash chrontatography

on silica gel $60(70-230$ mesh $)$.

Ozonolysis reactions: All ozonolyses were carried out in $50 \mathrm{~mL}$ of diclloromethane at $-78^{\circ} \mathrm{C}$ using excess ozone. Residual ozone was flushed out with nitrogen, the solvent was distilled off at room temperature under reduced pressure and the residue was separated by flash chromatography. All chromatography described below was carried out with dichloromethane/diethyl ether in a ratio of $15: 1$. The formaldehyde (3f) used in the coozonolysis was freslly prepared by pyrolysis of parafomaldehyde in each case

Reductions of ozonides: A solution of $20-40 \mathrm{mg}$ of an ozonide and an excess of triphenylphosphine in $0.6 \mathrm{~mL}$ of $\mathrm{CDCl}_{3}$ was kept at room temperature for 24 hours. The products were analy zed by ${ }^{1} \mathrm{H}$ NMR spectroscopy.

Caution: All ozonolysis reactions. cluromatograpluic separations. and reductions of ozonides were carried out behind protective safety glass shields in a hood. Ozonides were invariably transported. e.g. to the analytical laboratory, in thick-ivalled steel containers. Safety glasses and gloves must 
be worn.

Ozonolysis of $5 \mathrm{a}$ in the presence of $3 \mathrm{f}$ : Ozonolysis of $0.24 \mathrm{~g}(3.0 \mathrm{mmol})$ of $\mathbf{5 a}$ and $1 \mathrm{~mL}$ of $\mathbf{3 f}$ gave a liquid residue. from which $80 \mathrm{mg}(0.46 \mathrm{mmol}, 15.3 \%)$ of $10 \mathrm{c}$ and $60 \mathrm{mg}(0.43 \mathrm{mmol}, 14.2 \%)$ of $14 \mathrm{c}$ were isolated.

3-[2-(1,2,4-Trioxolane-3-yl)ethyl]-1,2,4-trioxolane (10c): Colorless liquid. ${ }^{1} \mathrm{H}$ NMR : $\delta 1.89$ (s. $\left.4 \mathrm{H}\right) .5 .07$ (s. $\left.2 \mathrm{H}\right) .5 .14$ (s. $2 \mathrm{H}), 5.27(\mathrm{t}, J=4.8 \mathrm{~Hz} .2 \mathrm{H}) .{ }^{13} \mathrm{C}$ NMR : $\delta 25.96,94.54$. 103. 10. Anal. Calcd for $\mathrm{C}_{6} \mathrm{H}_{10} \mathrm{O}_{6}$ (178.1): C. 40.45: H. 5.66. Found: C, 40.32: H. 5.68. Reduction of 10c with TPP gave butanedial.

(1,2,4-Trioxolane-3-yl)propanal $(1+c)$ : Colorless liquid. ${ }^{1} \mathrm{H}$ NMR : $\delta 1.93-2.05(\mathrm{~m} .2 \mathrm{H}), 2.49(\mathrm{t} . J=6.1 \mathrm{~Hz}, 2 \mathrm{H}) .4 .96$ (s. $1 \mathrm{H}$ ). 5.07 (s. $1 \mathrm{H}$ ). 5.17 (t. $J=5.2 \mathrm{~Hz}, 1 \mathrm{H}$ ), 9.67 (s. $1 \mathrm{H}$ ). ${ }^{13} \mathrm{C}$ NMR : $\delta$ 24.31. 37.80, 94.49, 103.44, 200.96. Anal. Calcd for $\mathrm{C}_{3} \mathrm{H}_{5} \mathrm{O}_{4}$ (132.1): $\mathrm{C}, 45.46 ; \mathrm{H}, 6.10$. Found: $\mathrm{C}$. 45.57: H, 5.23. Reduction of 14c with TPP gave butanedial.

3-[3-(1,2,4-Trioxolane-3-yl)]propy] $]-1,2,4$-trioxolane (10e): Yield. 26.7\%. Colorless liquid. ${ }^{1} \mathrm{H}$ NMR : $\delta 1.56-1.64$ (m. $2 \mathrm{H}), 1.75-1.8 \mathrm{l}(\mathrm{m} .+\mathrm{H}) .5 .03(\mathrm{~s}, 2 \mathrm{H}), 5.14(\mathrm{t}, J=4.9 \mathrm{~Hz}$. $2 \mathrm{H}), 5,17$ (s. $2 \mathrm{H}$ ). ${ }^{13} \mathrm{C} \mathrm{NMR}: \delta 18.43,30.69 .94 .43,103.64$. The data are identical to those reported.

(1,2,4-Trioxolane-3-yl)butanal (1te): Yield. 24.3\%. Colorless liquid. ${ }^{1} \mathrm{H}$ NMR : $\delta 1.65-1.75$ (m. $\left.4 \mathrm{H}\right), 2.46$ (t. $J=6.1 \mathrm{~Hz}, 2 \mathrm{H}) .4 .99$ (s. $1 \mathrm{H}), 5.08(\mathrm{t}, J=5.1 \mathrm{~Hz}, \mathrm{lH}) .5 .13$ $(\mathrm{s}, \mathrm{IH}), 9.65(\mathrm{~s}, \mathrm{IH}) .{ }^{13} \mathrm{C}$ NMR : $\delta$ 16.58. 30.77. 43.60, 94.41, 103.61. 202.10. The data are identical to those reported. ${ }^{5}$

3-[+-(1,2,4-Trioxolane-3-y])butyl]-1,2,4-trioxolane (10g): Yield. 28.2\%. Colorless liquid. ${ }^{~} \mathrm{H}$ NMR : $\delta 1.50$ (n. $4 \mathrm{H}$ ). $1.75(\mathrm{~m}, 4 \mathrm{H}) .5 .03$ (s. $2 \mathrm{H}), 5.13(\mathrm{t}, J=5.2 \mathrm{~Hz}, 2 \mathrm{H}) .5 .18$ (s. $2 \mathrm{H}) .{ }^{13} \mathrm{C}$ NMR : $\delta 23.95,31.34 .94 .42,103.86$. The data are identical to those reported.

(1,2,4-Trioxolane-3-yl)pentanal (14g): Yield, 26.6\%. Colorless liquid. ${ }^{1} \mathrm{H}$ NMR : $\delta 1.48(\mathrm{~m}, 2 \mathrm{H}) .1 .67-1.74(\mathrm{~m}$, $4 \mathrm{H}), 2.47$ (t. $J=6.2 \mathrm{~Hz} .2 \mathrm{H}), 5.02(\mathrm{~s} . \mathrm{HH}) .5 .13(\mathrm{t}, J=5.2$ Hz. $1 \mathrm{H}), 5.17$ (s, lH). 9.76 (s. $1 \mathrm{H}) .{ }^{13} \mathrm{C}$ NMR : $\delta 21.66 .23 .19$. $30.84,43.47,93.92,103.29,201.94$. The data are identical to those reported.

Ozonolysis of $\mathbf{5 a}$ in the presence of $3 \mathrm{~g}$ : Ozonolysis of $0.24 \mathrm{~g}(3.0 \mathrm{mmol})$ of $5 \mathrm{a}$ and $0.41 \mathrm{~g}(6.0 \mathrm{mmol})$ of $3 \mathrm{~g}$ gave a liquid residue, from which $100 \mathrm{mg}(0.38 \mathrm{mmol} .12 .8 \%)$ of $10 \mathrm{~d}$ and $70 \mathrm{mig}(0.40 \mathrm{mmnol}, 12.8 \%)$ of $14 \mathrm{~d}$ were isolated.

5-Cyano-5-methyl-3-[2-(5-cyano-5-methyl-1,2,4-trioxolane-3-yl)ethyl]-1,2,4-trioxolane (10d): Colorless liquid (a mixture of cis and trans isomers). ${ }^{1} \mathrm{H}$ NMR : $\delta 1.86(\mathrm{~s}, 6 \mathrm{H})$. $1.64-2.08(\mathrm{~m}, 4 \mathrm{H}) .[5.31(\mathrm{ml}), 5.72(\mathrm{ml})](2 \mathrm{H}),{ }^{13} \mathrm{C}$ NMR $\delta$ 21.11. 23.22. 23.96, 27.84, 28.39. 98.47. 99.00, 105.43. 116.21. 116.84. Anal. Calcd for $\mathrm{C}_{10} \mathrm{H}_{12} \mathrm{O}_{6} \mathrm{~N}_{2}(256.2)$ : C, 46.88; H. 4.72. Found: C, 46.64: H. 4.69. Reduction of 10d with TPP gave butanedial and acetyl cyanide.

(5-Cyano-5-methyl-5-1,2,4-trioxolane-3-yl)propanal (14d): Colorless liquid (a mixture of cis and trans isomers). ${ }^{1} \mathrm{H}$ NMR : $\delta 1.86(\mathrm{~s}, 3 \mathrm{H}) .[2.01(\mathrm{~m}) .2 .6 \mathrm{l}(\mathrm{t}, J=6.2 \mathrm{~Hz})](2 \mathrm{H})$. $[2.20(\mathrm{ml}) .2 .7 \mathrm{l}(\mathrm{t} . J=6.2 \mathrm{~Hz})](2 \mathrm{H}),[5.32(\mathrm{t} . J=5.2 \mathrm{~Hz})$. $5.74(\mathrm{t}, J=5.2 \mathrm{~Hz})](\mathrm{lH}) 9.79(\mathrm{~s}, 1 \mathrm{H}),{ }^{13} \mathrm{C} \mathrm{NMR}: \delta 21.07$. $22.55,26.70 .37 .05,37.76 .98 .40,98.98$. 105.86. 116.29 . 116.94, 200.27. Anal. Calcd for $\mathrm{C}_{7} \mathrm{H}_{9} \mathrm{O}_{4} \mathrm{~N}$ (171.1): C, 49.14:
H, 5.30. Found: C. 48.97; H, 5.37. Reduction of 14d with TPP gave butanedial and acetyl cyanide.

5-Cyano-5-methy]-3-[3-(5-cyano-5-methy]-1,2,4-trioxolane-3-yl) propyl]-1,2,4-trioxolane (10f): Yield. 24.3\%. Colorless liquid (a mixture of cis and trans isomers). ${ }^{1} \mathrm{H}$ NMR : $\delta 1.65-197(\mathrm{~m}, 6 \mathrm{H}), 1.86(\mathrm{~s}, 6 \mathrm{H}) .[5.28(\mathrm{t}, J=5.1$ Hz). $5.64(\mathrm{t}, J=5.1 \mathrm{~Hz})](2 \mathrm{H}) .{ }^{13} \mathrm{C}$ NMR $: \delta 17.73,21.30$, 29.45, 29.64. 33.43. 33.71, 98.65. 98.78, 106.32, 116.73, 116.96. Anal. Calcd for $\mathrm{C}_{11} \mathrm{H}_{14} \mathrm{O}_{6} \mathrm{~N}_{2}$ (270.2): C, 48.89: $\mathrm{H}$, 5.22. Found: C. 48.58; H, 5.37. Reduction of 10 with TPP gave pentanedial and acetyl cyanide.

(5-Cyano-5-methyl-1,2,4-tioxolane-3-yl)butanal (1+f): Yield. 24.1\%. Colorless liquid (a mixture of cis and trans isomers). ${ }^{1} \mathrm{H}$ NMR : $\delta 1.60-1.80(\mathrm{~m}, 4 \mathrm{H}) .1 .74(\mathrm{~s}, 3 \mathrm{H}) .2 .24$ (t. $J=6.2 \mathrm{~Hz} .2 \mathrm{H})[5.14(\mathrm{t} . J=5.1 \mathrm{~Hz}) .5 .52(\mathrm{t} . J=5.1 \mathrm{~Hz})]$ (lH). 9.63 (s. lH) ${ }^{13} \mathrm{C}$ NMR : $\delta$ 15.57. 15.78. 20.58, 20.61, $28.58,32.67 .42 .57 .42 .73,97.72 .98 .16,105.75,115.79$, 116.41.201.05. The data are identical to those reported.

5-Cyano-5-methy]-3-[+-(5-cyano-5-methy]-1,2,4-trioxolane-3-yl)butyl]-1,2,4-trioxolane (10h): Yield, 31.2\%. Colorless liquid (a misture of cis and trans isomers). ${ }^{1} \mathrm{H}$ NMR : $\delta$ $1.51-1.60(\mathrm{~m} .4 \mathrm{H}) .1 .71-1.89(\mathrm{~m} .4 \mathrm{H}), 1.86(\mathrm{~s} .6 \mathrm{H}),[5.26(\mathrm{t}$. $J=5.2 \mathrm{~Hz}), 5.62(\mathrm{t} . J=5.2 \mathrm{~Hz})](2 \mathrm{H}) .{ }^{13} \mathrm{C}$ NMR $: \delta 21.3 \mathrm{l}$. 23.38. 23.68, 29.77, 33.32, 98.72, 106.72. 117.03. Anal. Calcd for $\mathrm{C}_{12} \mathrm{H}_{16} \mathrm{O}_{6} \mathrm{~N}_{2}$ (284.2): C, $50.70, \mathrm{H}$ 5.67. Found: C. 50.58 ; $H, 5.58$. Reduction of $\mathbf{1 0 h}$ with TPP gave hexanedial and acetyl cyanide.

5-Cyano-5-methyl-1,2,t-trioxolane-3-yl)pentanal (1+h): Yield. $36.8 \%$. Colorless liquid (a mixture of cis and trans isomers). ${ }^{1} \mathrm{H}$ NMR : $\delta 1.37-1.81(\mathrm{~m}, 6 \mathrm{H}) .1 .79(\mathrm{~s}, 3 \mathrm{H}) .2 .42$ (t. $J=6.2 \mathrm{~Hz} .2 \mathrm{H}),[5.19(\mathrm{t} . J=5.1 \mathrm{~Hz}), 5.55(\mathrm{t} . J=5.1 \mathrm{~Hz})]$ (lH). $9.70(\mathrm{t}, J=1.59 \mathrm{~Hz}, \mathrm{IH}) .{ }^{13} \mathrm{C}$ NMR : $\delta 20.72 .20 .8 \mathrm{l}$, 21.30. 21.52, 22.84. 23.03, 29.27. 33.32, 43.27.97.85, 98.27, 106.19.116.00, 116.63. 202.14. The data are identical to those reported.

Ozonolysis of $6 \mathrm{a}$ in the presence of $3 \mathrm{f}$ : Ozonolysis of $0.24 \mathrm{~g}(3.0 \mathrm{mmol})$ of $\mathbf{6 a}$ and $1 \mathrm{~mL}$ of $3 \mathbf{3 f}$ gave a liquid residue, from which $390 \mathrm{mg}(2.35 \mathrm{mmol} .79 .3 \%)$ of $10 \mathrm{a}$ and $30 \mathrm{mg}(0.24 \mathrm{mmol}, 8.0 \%)$ of 14 a were isolated.

3-(1,2,4-Trioxolan-3-yl)methyl-1,2,4,-trioxolane (10a): Colorless liquid. ${ }^{1} \mathrm{H}-\mathrm{NMR}: \delta 2.18(\mathrm{~m}, 2 \mathrm{H}) .5 .14$ (s. $\left.4 \mathrm{H}\right)$, $5.39(\mathrm{t} . J=2.87 \mathrm{~Hz} .2 \mathrm{H}){ }^{13} \mathrm{C}$ NMR : $\delta 35.37 .94 .45 .100 .28$. Anal. Calcd for $\mathrm{C}_{5} \mathrm{H}_{8} \mathrm{O}_{6}$ (164.1): $\mathrm{C}, 36.60 ; \mathrm{H}, 4.91$. Found: C, 36.87: H. 5.11. Reduction of 10a with TPP gave propanedial.

(1,2,4,-trioxolane-3-yl)ethanal (14a): Colorless liquid. ${ }^{1} \mathrm{H}$ NMR : $\delta 2.90(\mathrm{~m}, 2 \mathrm{H}) .5 .13(\mathrm{~s}, 1 \mathrm{H}) .5 .19(\mathrm{~s} .1 \mathrm{H}), 5.67(\mathrm{t}, J=$ $7.12 \mathrm{~Hz} . \mathrm{lH}) .9 .77$ (t. $J=1.05 \mathrm{~Hz}, 1 \mathrm{H})$. ${ }^{13} \mathrm{C}$ NMR : $\delta 46.31$, 94.56, 99.99. 197.68. Anal. Calcd for $\mathrm{C}_{4} \mathrm{H}_{6} \mathrm{O}_{4}$ (118.1): $\mathrm{C}$, 40.68: H. 5.12. Found: C. 40.34; H. 5.31.

Reduction of 14 a with TPP gave propanedial.

Ozonolysis of $6 \mathrm{~b}$ in the presence of $3 \mathrm{f}$ : Ozonolysis of $0.32 \mathrm{~g}(3.0 \mathrm{mmol})$ of $6 \mathbf{6}$ and $1 \mathrm{~mL}$ of $3 \mathrm{f}$ gave a liquid residue, from which $160 \mathrm{mg}(0.45 \mathrm{mmol}, 30 \%)$ of $10 \mathrm{c}$ and $100 \mathrm{mg}(0.76 \mathrm{mmol}, 25.3 \%)$ of $14 \mathrm{c}$ were isolated.

Ozonolysis of $\mathbf{6 b}$ in the presence of $\mathbf{3 g}$ : Ozonolysis of

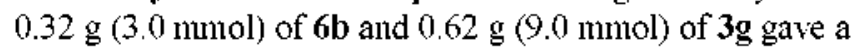


liquid residue, from which $120 \mathrm{mg}(0.86 \mathrm{mmol}$. $28.4 \%)$ of $10 \mathrm{~d}$ and $140 \mathrm{mg}(0.85 \mathrm{~mm}$ ol. $27.3 \%)$ of $1+\mathrm{d}$ were isolated.

Ozonolysis of $6 \mathrm{c}$ in the presence of $3 \mathrm{f}$ : Ozonolysis of $0.36 \mathrm{~g}(3.0 \mathrm{mmol})$ of $6 \mathrm{c}$ and $\mathrm{I} \mathrm{mL}$ of $3 \mathrm{f}$ gave a liquid reside. from which $510 \mathrm{mg}$ ( $1.75 \mathrm{mmol}, 58.3 \%)$ of 19 was isolated.

3-Formylmethy]-3-[5-(1,2,4-trioxolan-3-yl)-t-oxopenty]1,2,4,-trioxolane (19): Colorless liquid. ${ }^{~} \mathrm{H}$ NMR : $\delta 1.79$ (n. $2 \mathrm{H}$ ). 1.90 (m. $2 \mathrm{H}) .2 .54$ (t. $J=4.4 \mathrm{~Hz}, 2 \mathrm{H}), 2.84(\mathrm{~m}, 4 \mathrm{H})$, $5.08(\mathrm{~s}, \mathrm{IH}) .5 .15(\mathrm{~s}, \mathrm{lH}) .5 .29(\mathrm{~m} .2 \mathrm{H}), 5.63(\mathrm{t}, J=3.12 \mathrm{~Hz}$. $1 \mathrm{H}), 9.73(\mathrm{~s} . \mathrm{HH}),{ }^{13} \mathrm{C}$ NMR : $\delta 16.75,34.78 .43 .02,45.22$. 50.06, 93.74, 94.71. 99.83. 108.38. 198.18, 204.93. Anal. Calcd for $\mathrm{C}_{11} \mathrm{H}_{18} \mathrm{O}_{8}$ (276.2): C, 47.83; H. 5.84, Found: $\mathrm{C}$. 48.21: $\mathrm{H}, 5.47$.

\section{References}

1. Fata, W. I: Eman, W. F. J. Org. Chem. 1968. 33, 1656

2. Bailey. P. S.: Bath. S. S.: Dobinson. F.: Garcia-Sharp. F. J.:
Johnson. C. D. J. Org. Chem. 1961, 26,694

3. Pappas. J. I.: Keaveney. W. P.: Berger. M.: Rush. R. V. J. Org. Chent. 1968. 33. 787.

4. Callighan. R. H.: Wilt. M. H. J. Ong Chem. 1961. 26.5212

5. Shin. H. S.: Lee. C. W. Lee, J. Y:Huh, T. S. Eur J. Ong Chem. 2000. 335

6. Lee. J. Y; Lee, C. W. Huh. T. S. Bull Kowan Chem Soc. 1998. 19. 1244.

7. Griesbaum. K.: Ovez. B.: Huh. T. S.: Dong. Y. Liebigs . Am. 1995. 1571 .

8. Park. S. H.: Lee, J. Y.; Huh. T. S. Eur. J. Org Chem. 2001.3083.

9. Griesbaum. K: Greunig, K. J:; Volpp, W.: Jung. I. Ch. Chem. Ber. 1991. $124,947$.

10. Griesbaum. K.: Dong. Y. J. Ong Chem. 1997. 62.6129.

11. Park. S. H.: Huh. T. S. Buhl Korem Chent Soc. 2001. 22. 1277.

12. Huh. T. S. Bull. Korean Chem. Soc. 1998, 19, 1152.

13. Murray, R. W: Youssefyeh. R. D.; Story. P. R. J. Am. Chem Soc. 1967.89 .2429 